
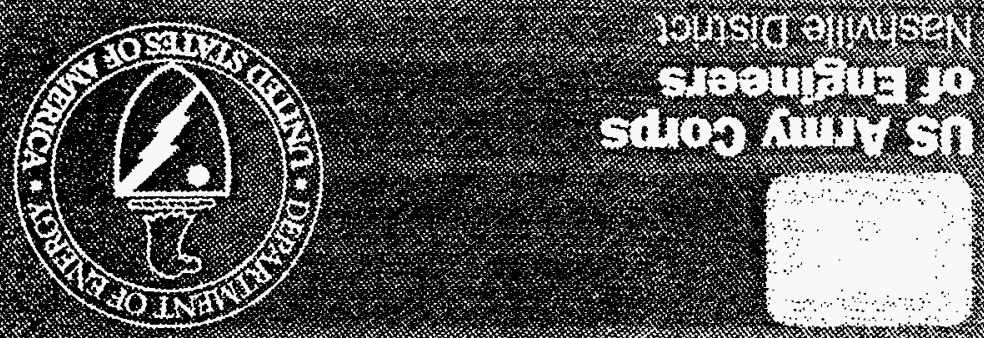

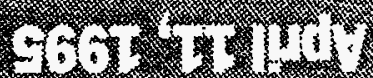

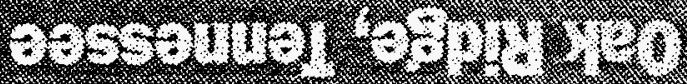
Nopeots L

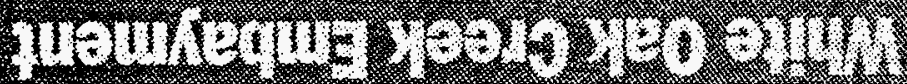

103

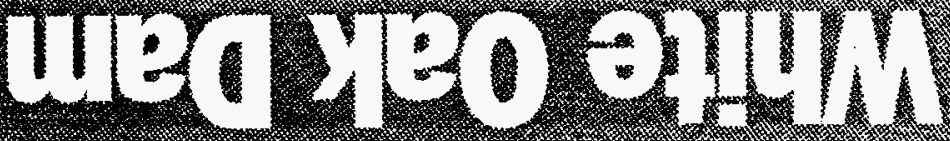 \\ 10

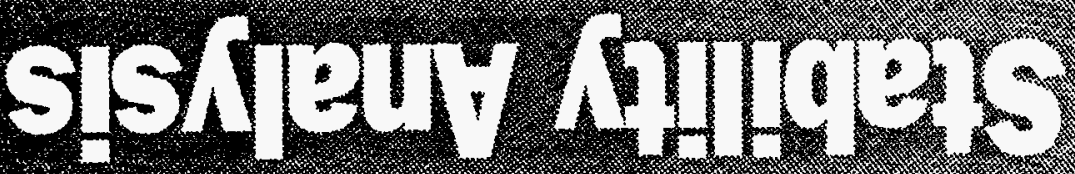




\title{
AI05-940R22246 DOE/OR/22246--T/
}

\author{
stability Analysis \\ of
}

White Oak Dam

U. S. Army Corps of Engineers

Nashville District

April 11, 1995

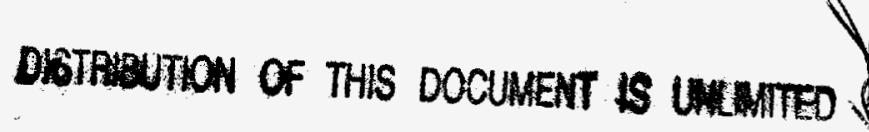




\section{DISCLAIMER}

Portions of this document may be illegible electronic image products. Images are produced from the best available original document. 


\section{DISCLAIMER}

This report was prepared as an account of work sponsored by an agency of the United States Government. Neither the United States Government nor any agency thereof, nor any of their employees, make any warranty, express or implied, or assumes any legal liability or responsibility for the accuracy, completeness, or usefulness of any information, apparatus, product, or process disclosed, or represents that its use would not infringe privately owned rights. Reference herein to any specific commercial product, process, or service by trade name, trademark, manufacturer, or otherwise does not necessarily constitute or imply its endorsement, recommendation, or favoring by the United States Government or any agency thereof. The views and opinions of authors expressed herein do not necessarily state or reflect those of the United States Government or any agency thereof. 


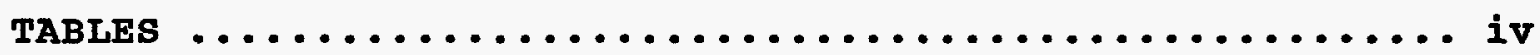

EXECUTIVE SUMMARY $\ldots \ldots \ldots \ldots \ldots \ldots \ldots \ldots \ldots \ldots \ldots \ldots \ldots \ldots \ldots \ldots$ SECTION

1.0 INTRODUCTION AND DESCRIPTION OF DAM $\ldots \ldots \ldots \ldots \ldots \ldots \ldots$

2.0 EXPLORATION AND TESTING $\ldots \ldots \ldots \ldots \ldots \ldots \ldots \ldots \ldots \ldots \ldots$

3.0 SOIL PROFILES $\ldots \ldots \ldots \ldots \ldots \ldots \ldots \ldots \ldots \ldots \ldots \ldots \ldots \ldots \ldots \ldots \ldots$

4.0 SOIL PARAMETERS ......................... 2

4.1 General ............................ 2

4.2 Rock Fill .............................

4.3 stiff silty clay .......................

4.4 Medium silty clay ........................ 6

4.5 soft silty clay ....................... 6

5.0 EARTHQUARE PARAMETERS $\ldots \ldots \ldots \ldots \ldots \ldots \ldots \ldots \ldots \ldots \ldots \ldots$

6.0 SLOPE STABILITY ANALYSIS $\ldots \ldots \ldots \ldots \ldots \ldots \ldots \ldots \ldots \ldots \ldots \ldots \ldots \ldots . \ldots \ldots$

6.1 Sections Analyzed ...................... 6

6.2 Cases Analyzed .........................

6.3 Results .............................. 7

7.0 LIQUEFACTION ANALYsIS ..................... 12

8.0 DISCUSSION OF RESULTS ..................... 12

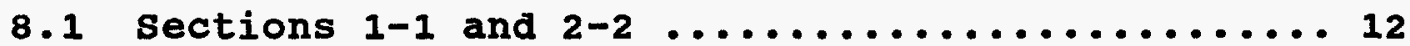

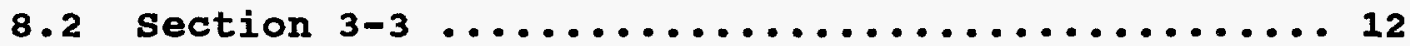

8.3 Conclusions ......................... 12

9.0 REVIEW AND COMPARISON OF OTHER STUDIES .......... 14

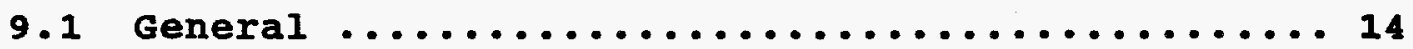

9.2 Soil Profiles .......................... 14

9.3 Soil Parameters ......................... 14

9.4 slope stability Analysis .................. 14

9.5 Comments on slope stability Analyses by syed

Ahmed ............................ 15

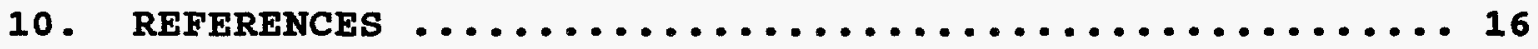




\section{FIGURES}

1. White Oak Dam Boring Location plan $\ldots \ldots \ldots \ldots \ldots \ldots \ldots \ldots$

2. Typical soil Profiles, sections 1-1, 2-2 and 3-3 .....4

3. Shear strength Envelopes ...................... 9

4. Stability Analysis, section 1-1 ................ 10

5. Stability Analysis, section $2-2 \ldots \ldots \ldots \ldots \ldots \ldots \ldots \ldots \ldots$

6. Stability Analysis, section $3-3 \ldots \ldots \ldots \ldots \ldots \ldots$ 
1. Material Properties $\ldots \ldots \ldots \ldots \ldots \ldots \ldots \ldots \ldots \ldots \ldots \ldots \ldots \ldots \ldots$

2. Minimum Factors of safety ..................... 


\section{EXECUTIVE SUMMARY}

White Oak Dam is located in the white oak Creek watershed which provides the primary surface drainage for Oak Ridge National Laboratory. A stability analysis was made on the dam by syed Ahmed in January 1994 which included an evaluation of the liquefaction potential of the embankment and foundation. This report evaluates the stability of the dam and includes comments on the report prepared by Ahmed.

Slope stability analyses were performed on the dam and included cases for sudden drawdown, steady seepage, partial pool and earthquake. Results of the stability analyses indicate that the dam is stable and failure of the structure would not occur for the cases considered.

The report prepared by Ahmed leads to the same conclusions as stated above. Review of the report finds that it is complete, well documented and conservative in its selection of soil parameters. The evaluation of the liquefaction potential is also complete and this report is in agreement with the findings that the dam and foundation are not susceptible to liquefaction. 


\section{SECTION 1.0 INTRODUCTION AND DESCRIPTION OF DAM}

White Oak Dam is an earth and rockfill structure over white oak creek and located about 0.6 miles above the confluence with the Clinch River. It was originally constructed in the early 1940's as a roadway with a box culvert located at the south end to carry flow from White oak creek under it. In 1943 a sheetpile cofferdam was constructed around the culvert to allow the roadway to serve as an embankment and impound a lake. In 1980 a rock stability berm was added to the downstream slope. An emergency spillway was constructed on the north end in 1983 and the roadbed was realigned to its present configuration.

The dam is approximately 300 feet long and its height varies from 15 to 25 feet with a top crest elevation of 755t. The width of the dam varies from 60 to 80 feet as it supports a two lane, 40 foot wide highway. The downstream slope varies from $1 \mathrm{~V}: 2 \mathrm{H}$ to IV: $3 \mathrm{H}$ while the upstream slope is steeper in places ranging from $1 \mathrm{~V}: 1.5 \mathrm{H}$ to $1 \mathrm{~V}: 3 \mathrm{H}$. Normal upstream pool elevation is 744 feet.

Although the dam was constructed initially as a roadway, no construction records are available. Additional details of the dam can be found in the report "White Oak Dam Stability Analyses," Volume I, No. X-OE-708, by Syed B. Ahmed.

\section{SECTION 2.0 EXPLORATIONS AND TESTING}

An initial exploration program was conducted by GEOTEK Engineering Company in 1979 which consisted of ten (10) borings. standard Penetration Tests (SPT) were performed in five (5) of the holes and shelby tube samples were taken from four (4) holes. Both SPT measurements and shelby tube samples were taken from boring No. 6. Casagrande type piezometers were also installed in two of the borings. Testing consisted of natural moisture contents, Atterberg limits and grain size analysis on the SPT and Shelby tube samples. Unconfined compression tests were performed on the undisturbed samples from the Shelby tubes. Modified Proctor compaction tests were conducted on a combined sample by mixing representative soils from the borings. Consolidation and permeability tests were also performed.

In 1987-88 Geologic Associates performed a second exploration program which consisted of 12 borings. These borings were SPT's with undisturbed shelby tube samples taken at selected depths. Natural water content and Atterberg limits were determined on representative samples. Triaxial tests were made on one shelby tube sample. 
Results of the laboratory testing can be found in "GEOTEK Report, "Evaluation of White Oak Dam" Geotek Project No. 79-687B, dated Nov. 14, 1979 and in "GEOLOGIC ASSOCIATES, EDGE, report, "White Oak Dam Investigation" GA File No. 88-X503, dated April 12, 1988 .

Locations of all the explorations can be found on Figure 1 .

\section{SECTION 3.0 SOIL PROFILES}

Based on the soil borings and results from the testing performed on the samples, soil profiles for three cross sections through the dam were generated. The index property testing indicated that the dam and foundation are made up of silts and silty clays. However, from the blowcounts of the SPT's, these soils can be further divided into soft, medium and stiff silts and silty clays. These profiles are shown on Figure 2 .

\section{SECTION 4.0 SOIL PARAMETERS}

4.1 General: The soil parameters used in the stability analyses were based on testing performed on undisturbed samples and from empirical correlations. Table 1 lists these parameters which include moist and saturated unit weights, and the $R$ and $S$ shear strengths. Below is a brief description of the basis for selection of these parameters for each of the materials.

4.2 Rock Fill: The parameters for the rock fill are based on empirical correlations and are considered to be very reliable for this type of material. Moist and saturated unit weights of 120 and 135 pcf, respectively, were used and, because it is pervious, the $R$ and $S$ strength was the same, which is a phi of 35 degrees.

4.3 Stiff silty clay: Unconfined compressive tests were made on this material, but no triaxial shear strength tests were performed. However, the high blowcounts recorded (10 to 15) are generally indicative of compacted materials of a levee or embankment. A well compacted fill such as a levee, embankment or roadfill can behave as an overconsolidated material and the $s$ strength will result in a phi angle with a small cohesion (c) intercept. In a study by Lovell and Johnson, "Shearing Behavior of Compacted clay after Saturation" compacted clays had S strengths in the range of 30 to 35 degrees phi with a cohesion range of 0 to 500 psf. The $R$ strength generally ranges from 1000 to 2000 psf for cohesion and 15 to 25 degrees for phi. Clay foundations with comparable blowcounts as at this site had a cohesion of 1000 psf and phi of 26 degrees. Because no triaxial tests were performed, conservative values of $R$ and $S$ were chosen. For the $S$ strength a phi of 31 degrees and cohesion of 275 psf were selected and for the $R$ strength, $a$ cohesion of 1000 psf and phi of 18 degrees were used. The unit 


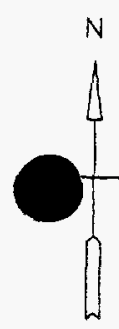

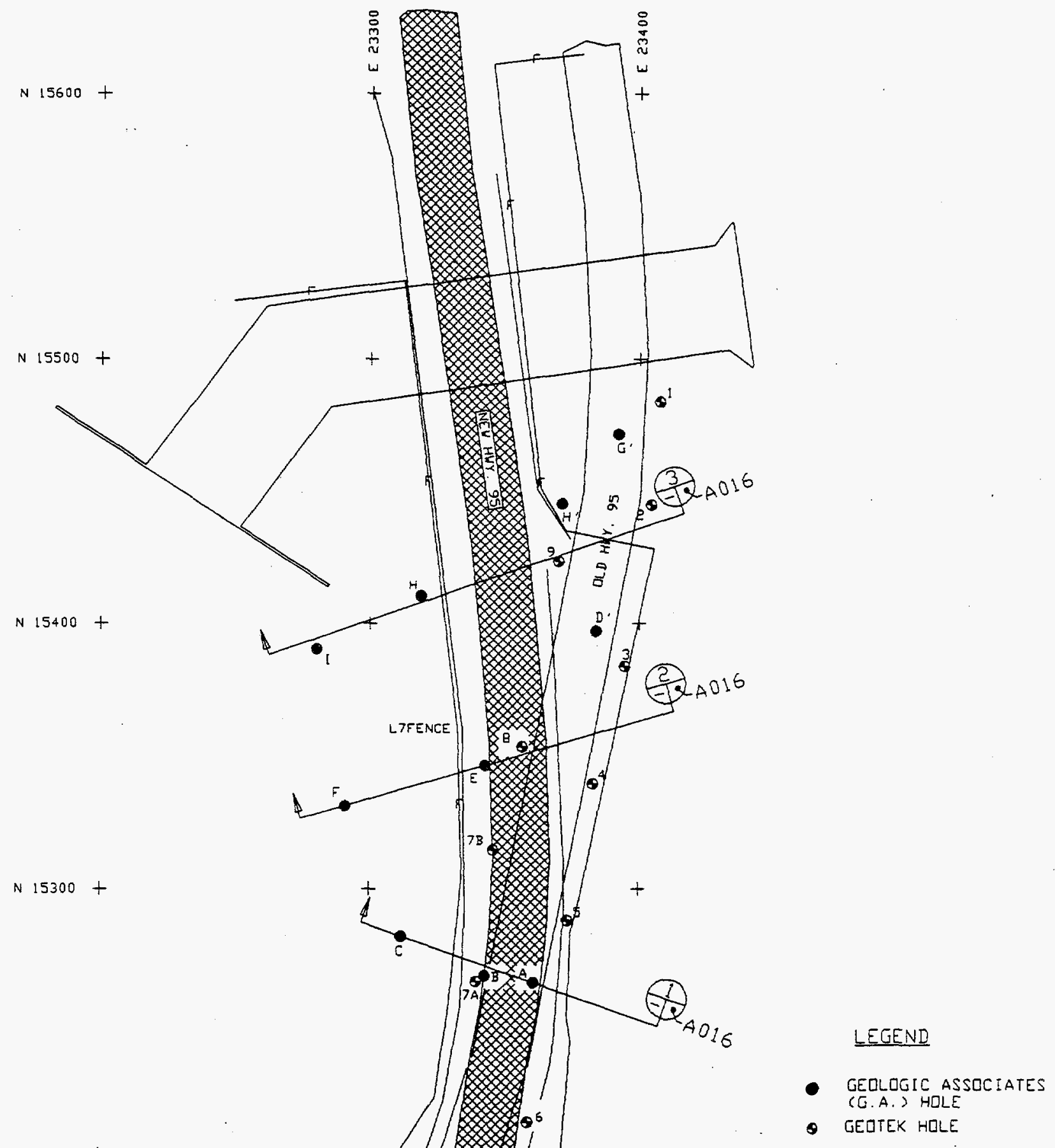

N $15200+$

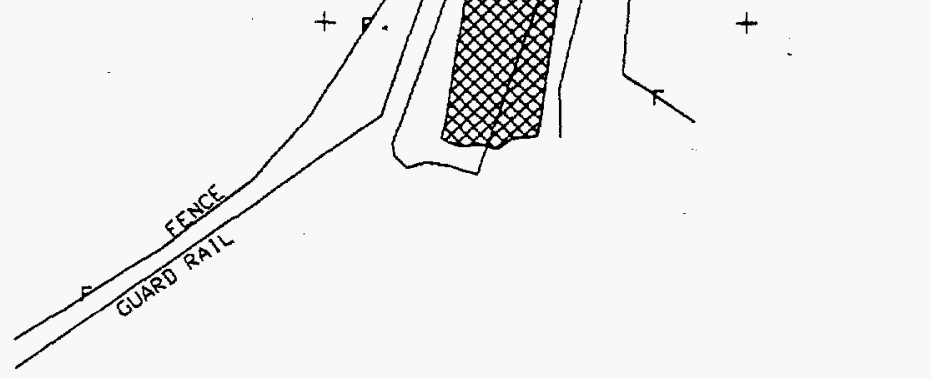

- GedTEK HILE

Figure 1 White Oak Dam Boring Location Plan, Scale: 1" $=60^{\prime}$ 


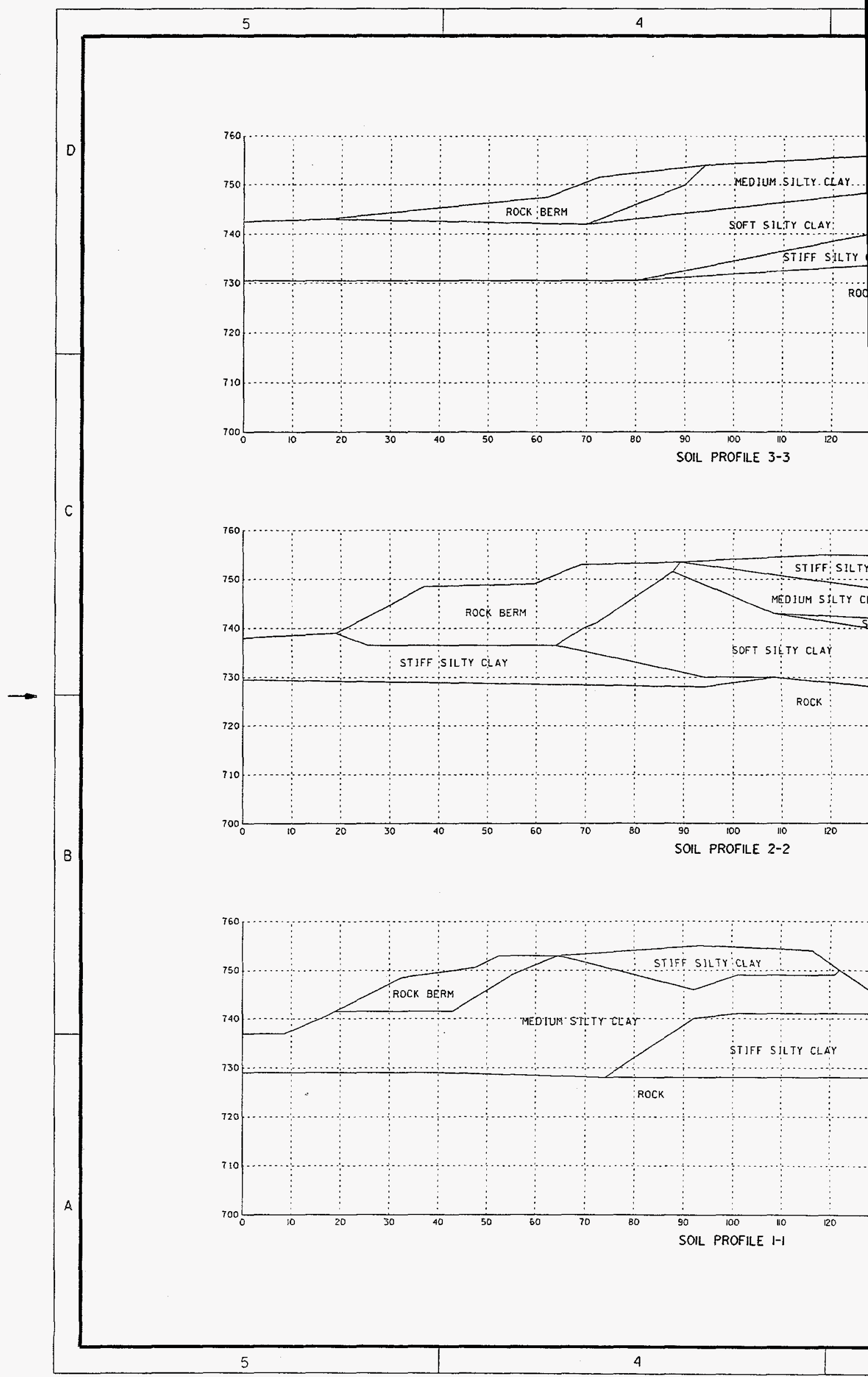




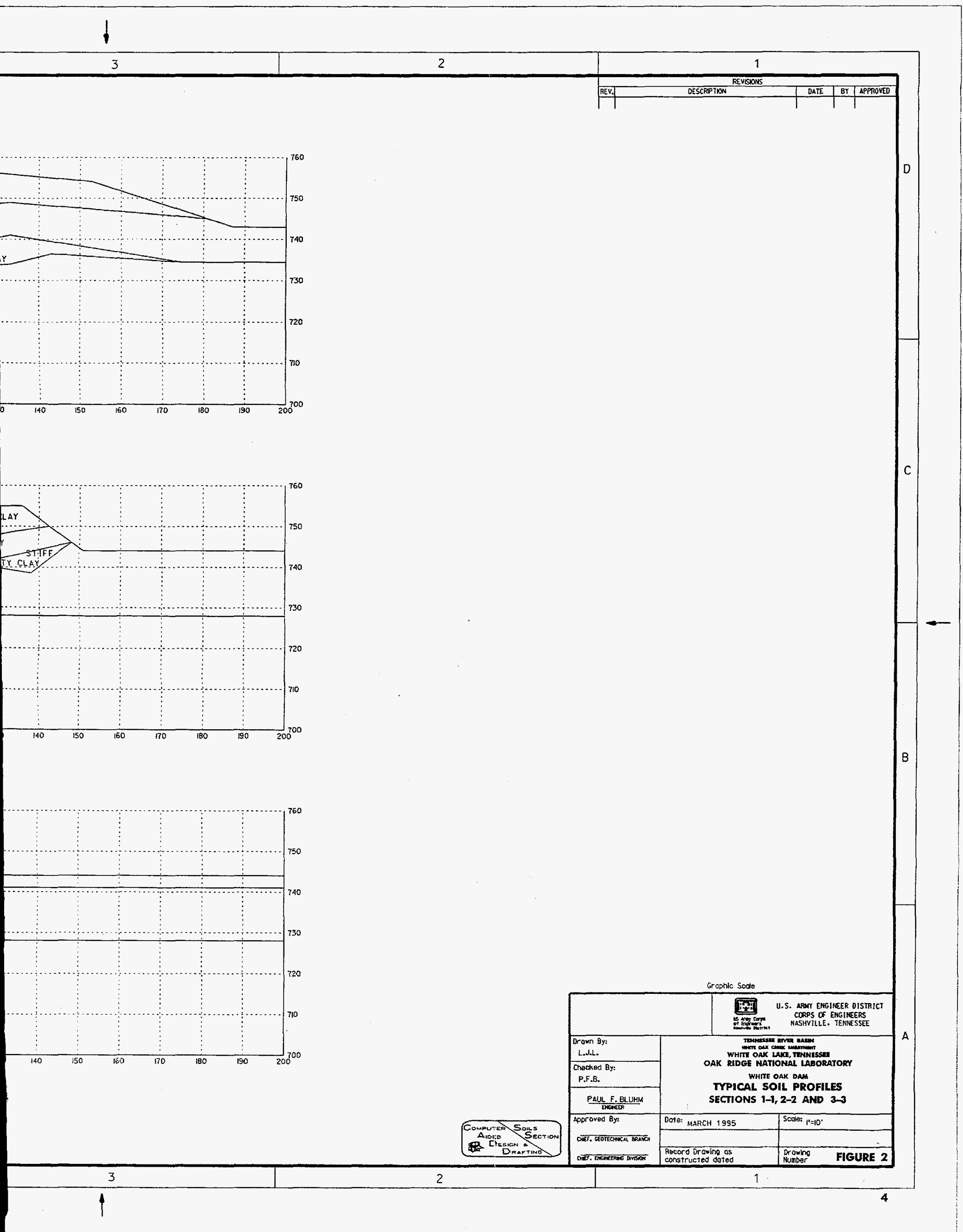


TABLE I

MATERIAL PROPERTIES

\begin{tabular}{|l|c|c|c|c|c|c|}
\hline \multicolumn{1}{|c|}{ MATERIAL } & UNIT WT. & UNIT WT. & \multicolumn{2}{|c|}{ S STRENGTH } & \multicolumn{2}{|c|}{ R STRENG TH } \\
\cline { 5 - 7 } \\
\hline $\begin{array}{l}\text { SOFT SILTY } \\
\text { CLAY }\end{array}$ & 116 & 118 & 0 & 26 & 200 & 14 \\
\hline $\begin{array}{l}\text { MED IUM ST IFF } \\
\text { SILTY CLAY }\end{array}$ & 119 & 121 & 0 & 28 & 245 & 16 \\
\hline $\begin{array}{l}\text { STIFF SILTY } \\
\text { CLAY }\end{array}$ & 122 & 125 & 275 & 31 & 1000 & 18 \\
\hline ROCKF ILL & 120 & 135 & 0 & 35 & 0 & 35 \\
\hline
\end{tabular}


weights as determined from the undisturbed samples are 122 and 125 pcf for moist and saturated unit weights, respectively.

4.4 Medium silty clay: One R bar triaxial test was performed on this material and the test resulted in an $s$ strength of phi of 28 degrees and an R strength of cohesion of 245 psf and a phi of 16 degrees. The unit weights from the undisturbed sampling were 119 and 121 pcf for the moist and saturated unit weights, respectively.

4.5 Soft silty clay: Unconfined compressive tests were made on this material, but no triaxial shear strength tests were performed. The results from the unconfined compressive strength tests ranged from 285 to $425 \mathrm{psf}$. In the third edition of "Foundation Analysis and Design" by Bowles (page 60) representative values of phi for a clay are given which, for an $R$ test, phi ranges from 3 to 20 degrees while for an $S$ test, phi ranges from 20 to 42 degrees. This represents a wide range of strength parameters and selection of the lower range may be unduly conservative. However, because this dam has been in existence for almost 50 years with no signs of deformation of the structure, back calculation of the strength values for this material is deemed appropriate. The sudden drawdown case is the most critical condition to evaluate in terms of slope stability. There are three documented cases of sudden drawdown occurring over the life of this project. The first time was in December 1990, the second in February 1994 and the third in March 1994. After each occurrence, the dam was inspected and movement measurements were made on monuments on the dam. No signs of cracks, bulges at the toe, distress to the embankment or slope instability were observed (inspection reports are on file at the Oak Ridge National Laboratory). The strength of the soft silty clay was then determined by back calculating for the sudden drawdown condition (from elevation 750) for a factor of safety of 1.0. This resulted in an $S$ strength of 26 degrees phi and an $R$ strength of 200 psf cohesion and 14 degrees phi. Depending on the depth of the material, these values will approximate the strengths from the unconfined compressive strength tests. The unit weights assumed were 116 and 118 pcf for the moist and saturated unit weights, respectively.

\section{SECTION 5.0 EARTHQUARE PARAMETERS}

After reviewing the reference material presented, the acceleration of $0.13 \mathrm{~g}$ is accepted as the appropriate earthquake motions for this site and is judged to be conservative.

\section{SECTION 6.0 SLOPE STABILITY ANALYSIS}

6.1 Sections Analyzed: Three sections were analyzed as shown on Figure 2 and they represent the areas where the explorations were 
performed. They are generally located at the north and south ends and in the middle of the dam. The computer program UTEXAS2 was used to perform these analyses and this program can perform the calculations by one of several methods. The method selected for this report was that developed by spencer using the procedure of method of slices to analyze a circular shear surface.

6.2 Cases Analyzed: The cases analyzed are those listed in Table 1 of the Corps of Engineers Manual, EM 1110-2-1902 (see page following this section for copy of this table), except for Case I, End of Construction. Because the dam has been in use for a number of years, this case is not necessary to analyze. The pool elevations and strength parameters for each case are given below.

6.2.1 Case II: This is sudden drawdown from maximum pool which is elevation 755. The shear strength envelope is a composite of the $\mathrm{R}$ and $\mathrm{S}$ strength envelopes and is shown on Figure 3 .

6.2.2 Case III: This is sudden drawdown from top of gates which is elevation 750. The shear strengths are the same as for Case II.

6.2.3 Case IV: This is partial pool with steady seepage (upstream slope). Because there is only 6 feet between the top of gates (elevation 750) and the normal low pool (elevation 744), the top of gates elevation was used. The composite of the $R$ and $S$ strength envelopes as shown on Figure 3 was used.

6.2.4 Case v: This is steady seepage for maximum storage pool (downstream slope) which was taken to be elevation 750 . The shear strengths are same as for Case IV.

6.2.5 Case VI: This is steady seepage with surcharge pool (downstream slope) which was taken to be elevation 755 . The shear strengths are the same as for case IV.

6.2.6 Case VII: This is the earthquake case where the minimum circles for cases IV and $V$ are analyzed. A seismic coefficient of $0.13 \mathrm{~g}$ was used.

6.3 Results: Computer printouts of the three sections analyzed and are on file at the Nashville District office. Below is a summary of the results.

6.3.1 Sections 1-1 and 2-2: Results of each of the respective cases for these two sections are shown on Figures 4 and 5. For Cases II, III and IV, the circles shown are for factors of safety of $1.0,1.2$ and 1.5 (the minimum required by EM 1110-21902), respectively. However, there are failure circles that are shallower (i.e. the circle was closer to the face of the slope) than those shown on Figures 4 and 5 with factors of safety less than that stated above. A discussion of the significance of this 
Table

Minimum Factors of Safetyl

\begin{tabular}{|c|c|c|c|c|}
\hline $\begin{array}{l}\text { Case } \\
\text { No. } \\
\end{array}$ & Design Condition & $\begin{array}{l}\text { Minimum } \\
\text { Faclor of } \\
\text { Salety }\end{array}$ & Shear: Strength & Remarks \\
\hline$I$ & End of construction & $1.3 \%$ & $Q$ or $S f$ & $\begin{array}{l}\text { Upstream and downstream } \\
\text { slopes }\end{array}$ \\
\hline II & $\begin{array}{l}\text { Sudden drawdown from } \\
\text { maximum pool }\end{array}$ & $1.0 \mathrm{t}$ & $R, S$ & $\begin{array}{l}\text { Upstream slope only. Use com- } \\
\text { posite envelope. See fig. } 4\end{array}$ \\
\hline III & $\begin{array}{l}\text { Sudden drawdown from } \\
\text { spillway crest or top } \\
\text { of gates }\end{array}$ & $1.2+t$ & $R, S$ & $\begin{array}{l}\text { Upstream slope only. Use com- } \\
\text { posite envelope. See fig. } 4\end{array}$ \\
\hline IV & $\begin{array}{l}\text { Partiăl pool with } \\
\text { steady seepage }\end{array}$ & 1.5 & $\begin{array}{l}\frac{R+S}{2} \text { for } R<S \\
S \text { for } R>S\end{array}$ & $\begin{array}{l}\text { Upstream slope only. Use in- } \\
\text { termediate envelope. See } \\
\text { fig. } 5\end{array}$ \\
\hline VI & $\begin{array}{l}\text { Steady seepage with } \\
\text { maximum storage pool } \\
\text { Steady seepage with } \\
\text { surcharge pool }\end{array}$ & $\begin{array}{l}1.5 \\
1.4\end{array}$ & $\begin{array}{c}\frac{R+S}{2} \text { for } R<S \\
S \text { for } R>S\end{array}$ & $\begin{array}{l}\text { Downstream slope only. Use } \\
\text { intermediate envelope. See } \\
\text { fig. } 5\end{array}$ \\
\hline VII & $\begin{array}{l}\text { Earthquake (Cases } I \text {, } \\
\text { IV, and V with } \\
\text { seismic loading) }\end{array}$ & 1.0 & $\oint$ & $\begin{array}{l}\text { Upstream and downstream } \\
\text { slopes. }\end{array}$ \\
\hline
\end{tabular}

1 Not applicable to embankments on clay shale foundations.

tl For embankments over $50 \mathrm{ft}$ high on relatively weak foundations use minimum factor of safety of 1.4 .

\$ In zones where no excess pore water pressures are anticipated, use $S$ strength.

11 The safety factor should not be less than 1.5 when drawdown rate and pore water pressures developed from flow nets (Appendix MII) are used in stability analyses.

\$ Use shear strength for case analyzed without earthquake except that it is not necessary to analyze sudden drawdown for tarthquake effects. 


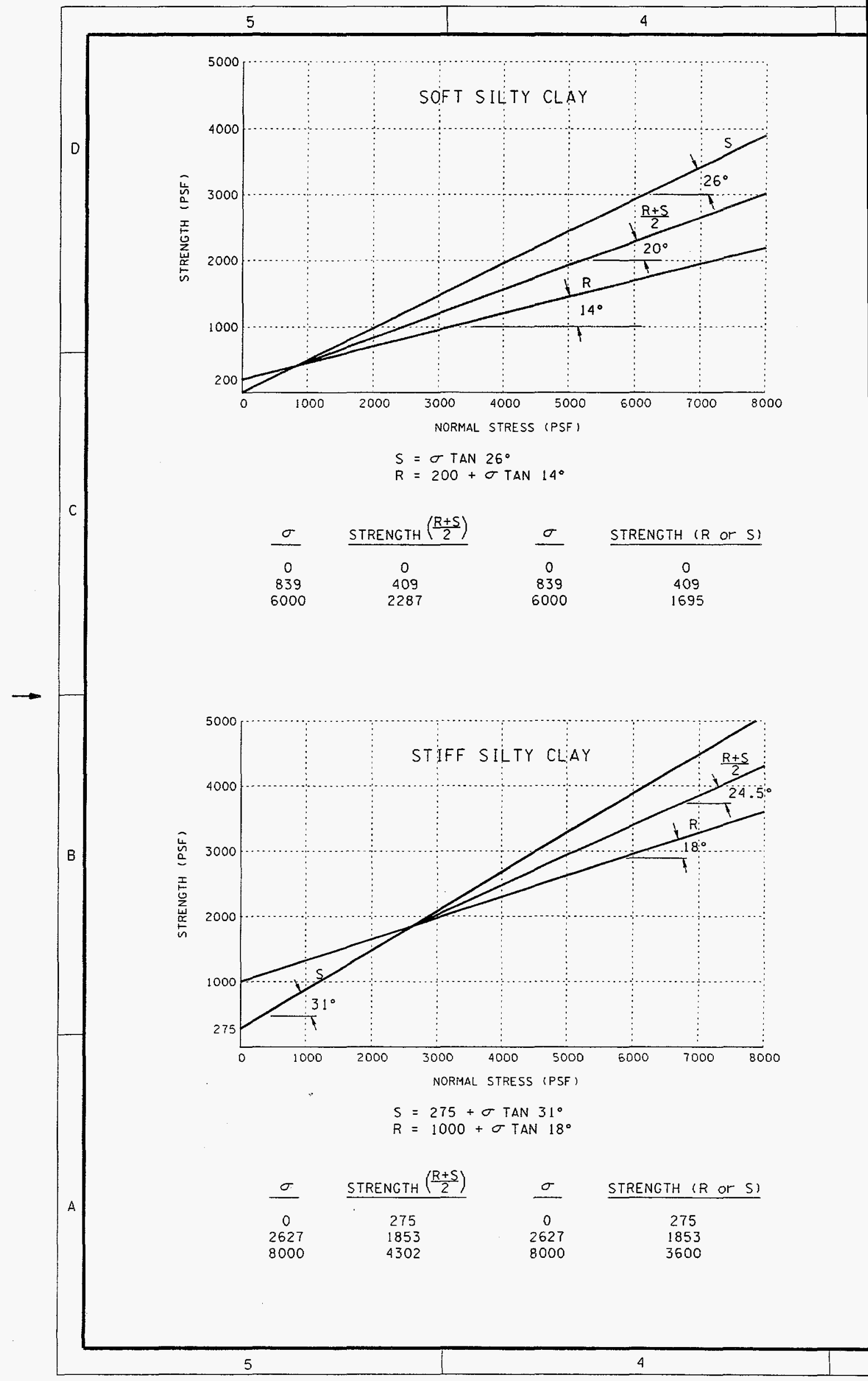




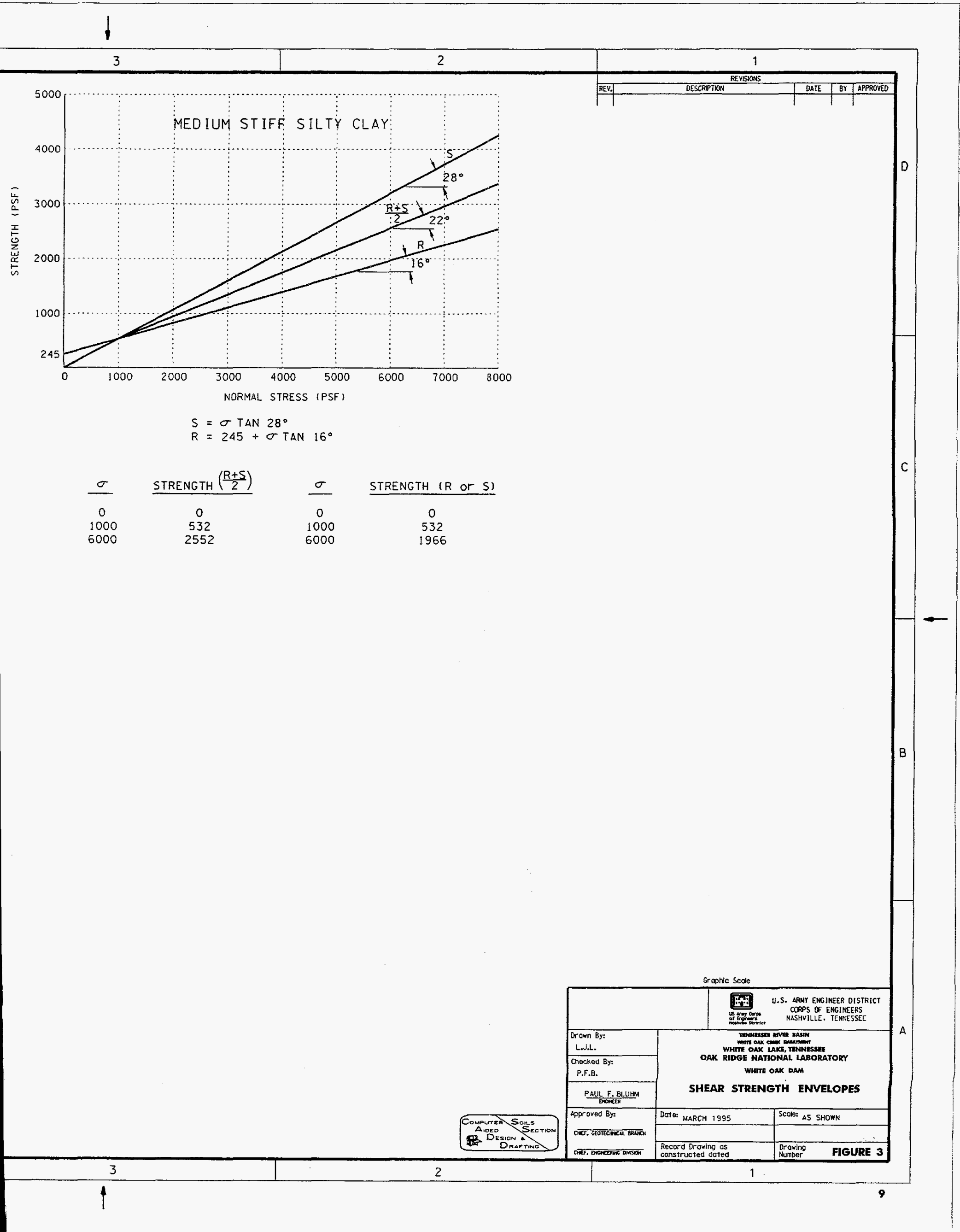




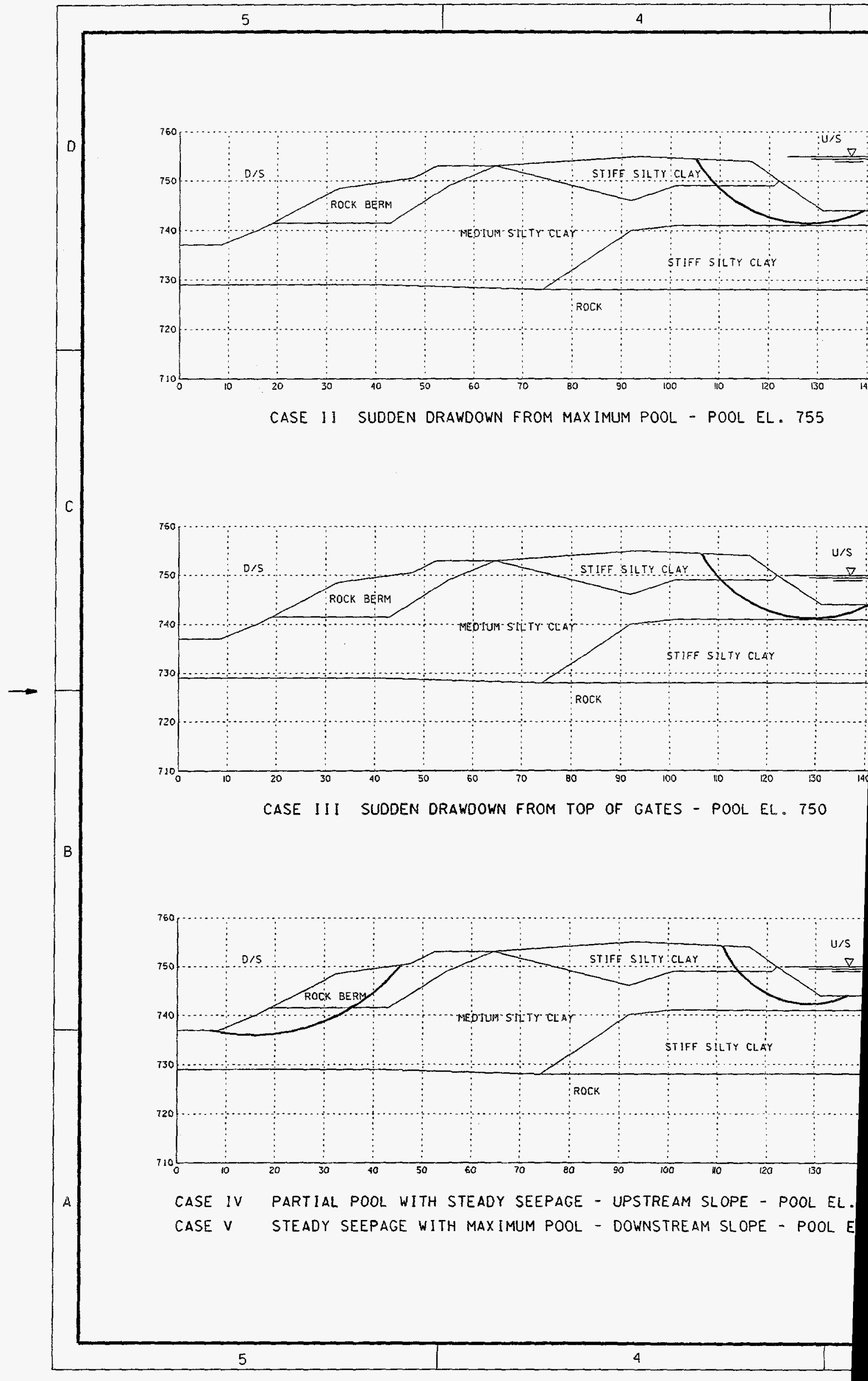




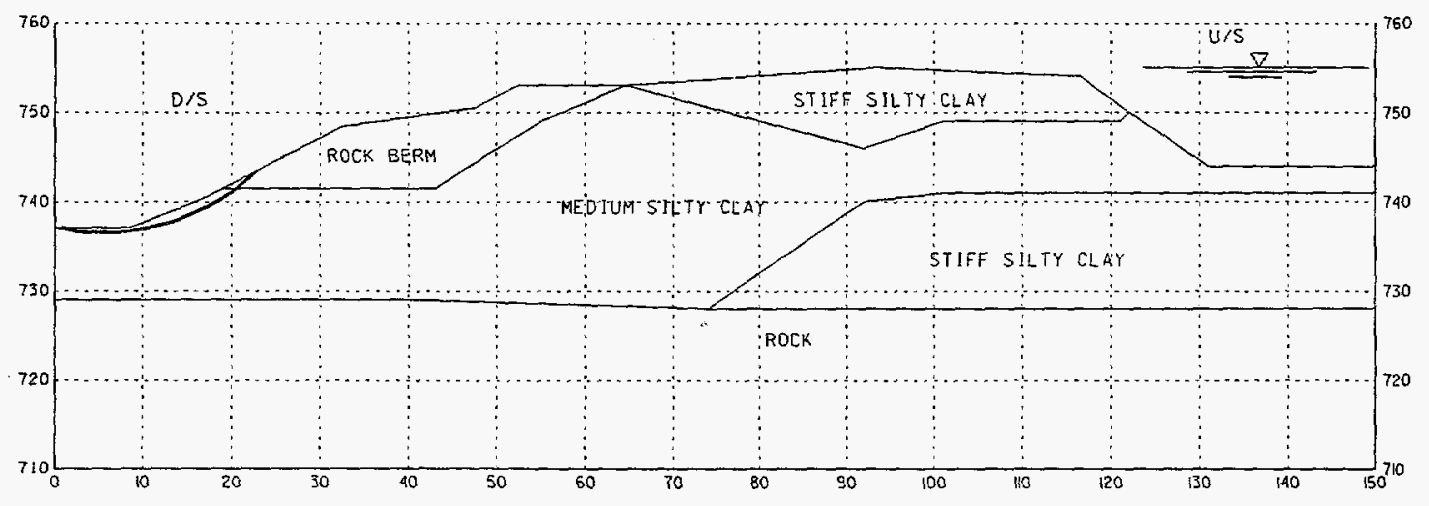

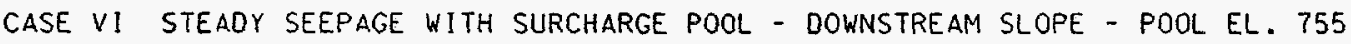

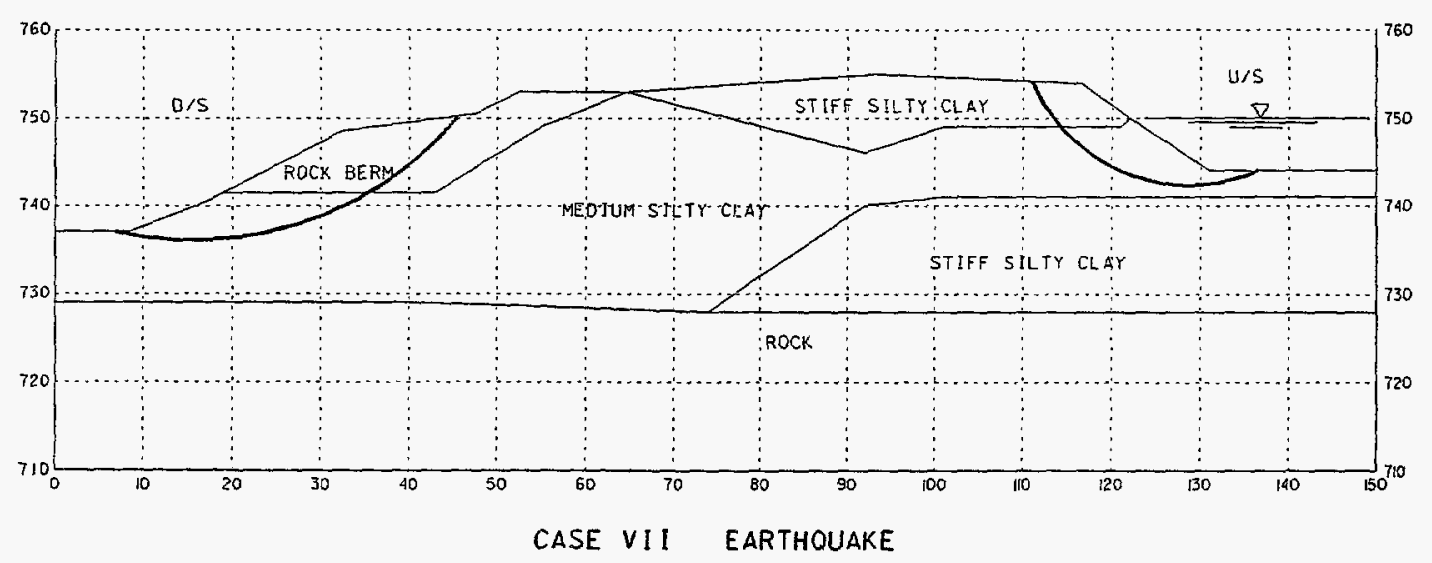

\begin{tabular}{|c|c|c|c|c|}
\hline CASE & $X$ & $Y$ & RAD. & $F .5$. \\
\hline II & 128.1 & 768.1 & 26.7 & 1.0 \\
\hline III & 129.0 & 767.0 & 25.75 & 1.2 \\
\hline IV & 128.75 & 761.55 & 19.2 & 1.6 \\
\hline V & 15.5 & 775.0 & 39.0 & 1.5 \\
\hline VI & 5.55 & 761.4 & 24.9 & 1.4 \\
\hline $\begin{array}{c}\text { VII } \\
\text { (IV) }\end{array}$ & 128.75 & 761.55 & 19.2 & 1.1 \\
\hline VII & 15.5 & 775.0 & 39.0 & 1.0 \\
(V) & 15 & & &
\end{tabular}




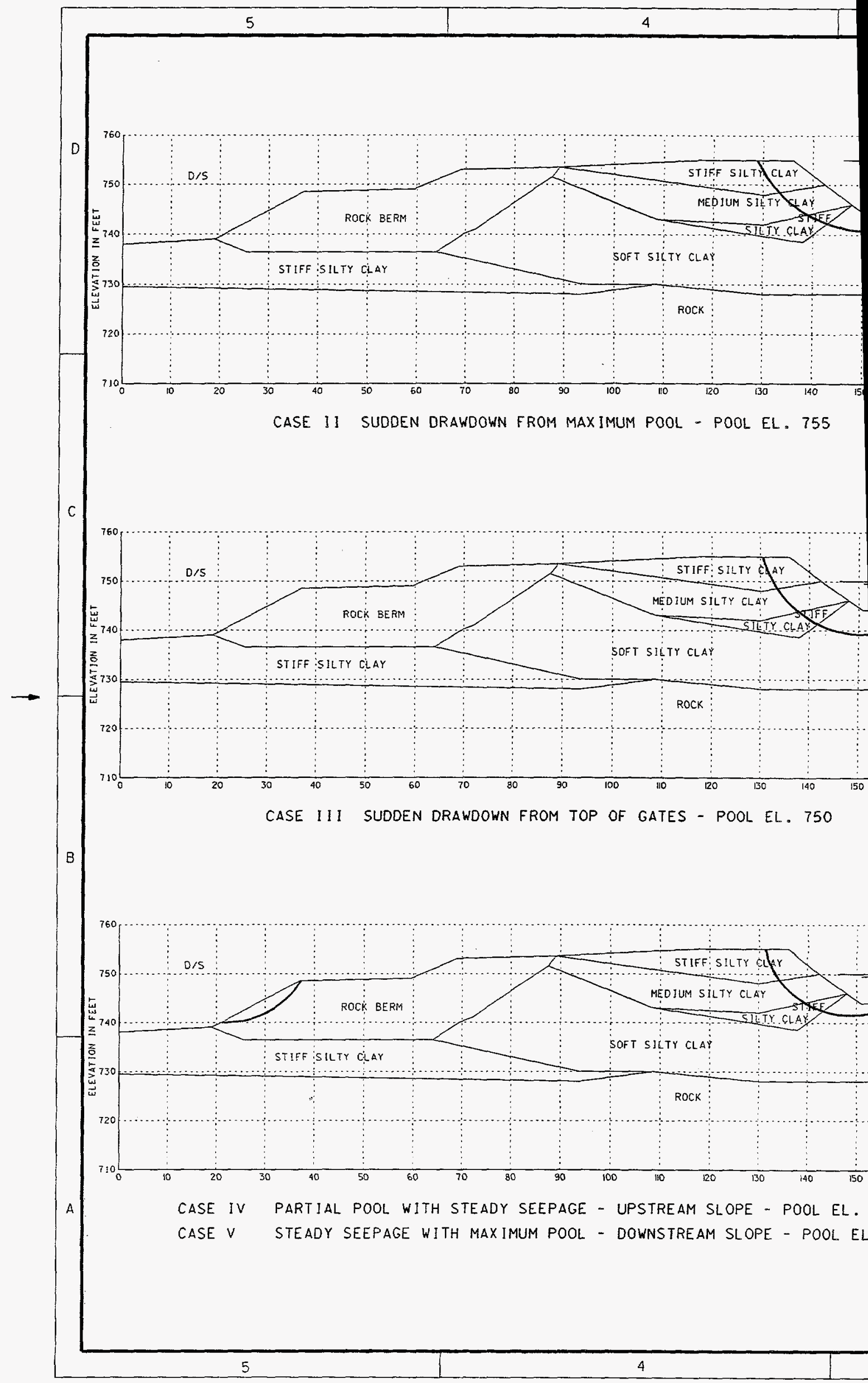



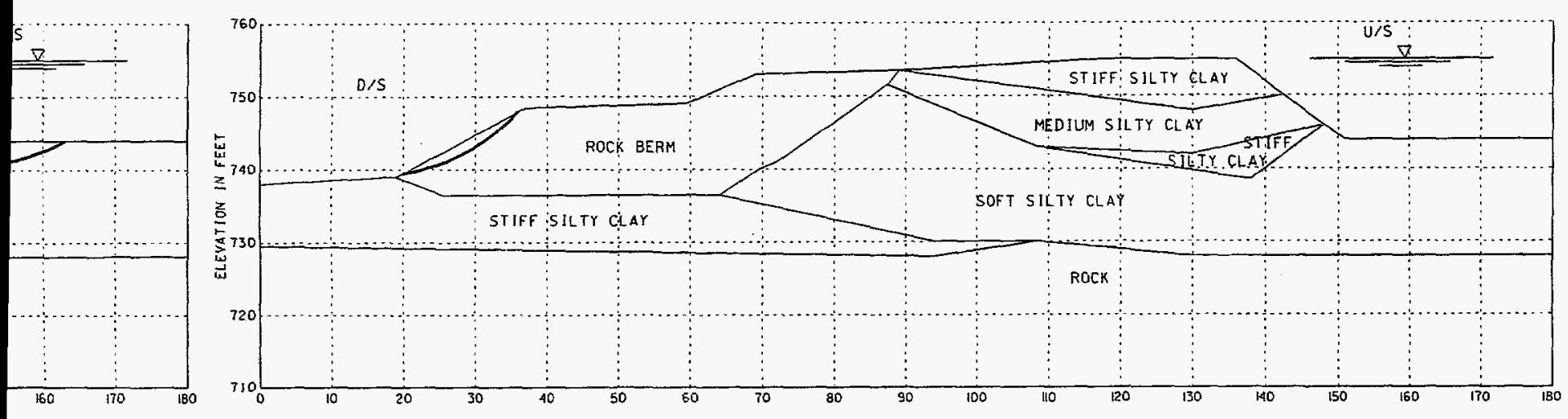

CASE VI STEADY SEEPAGE WITH SURCHARGE POOL - DOWNSTREAM SLOPE - POOL EL 755
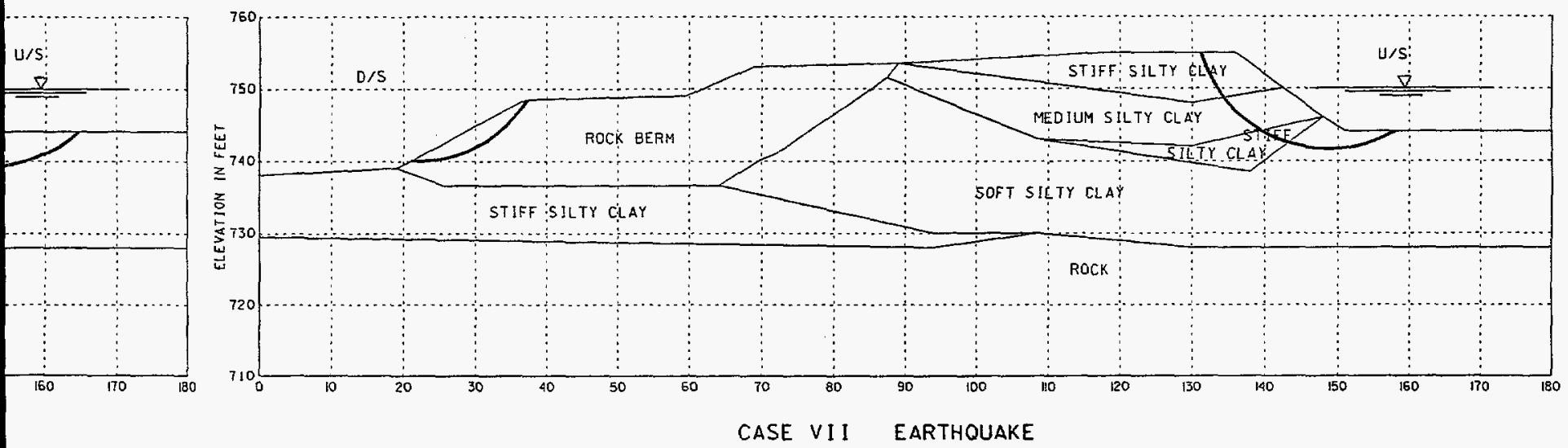

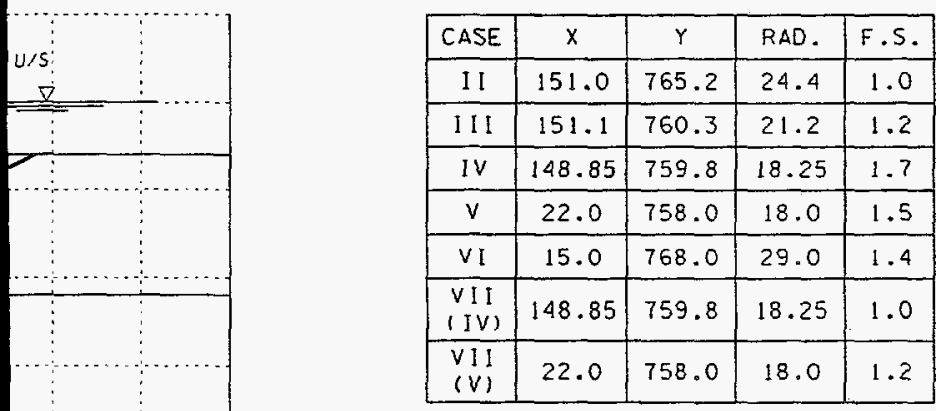

$160 \quad 170 \quad 180$

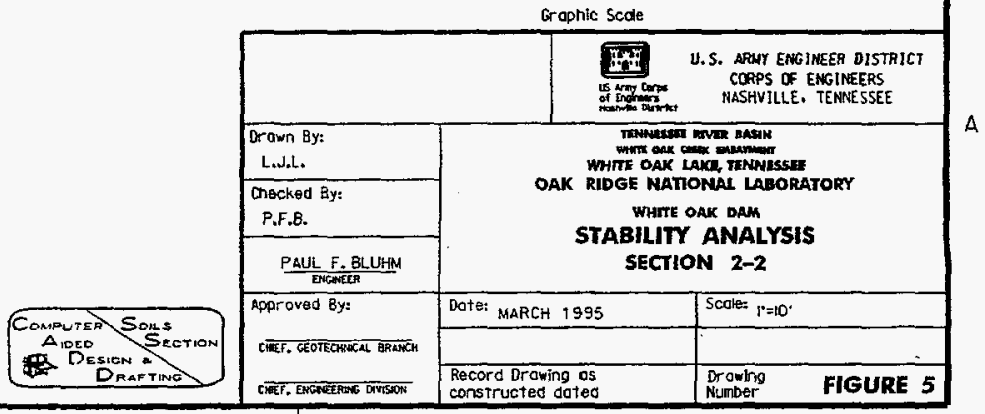


is given in paragraph 8.1. For Cases $V$ and VI, the circles shown represent the failure circle with the minimum factor of safety and they are greater than the minimum required by EM 1110-2-1902.

6.3.3 Section 3-3: Results of the minimum factors of safety for the respective cases and minimum circles are shown on Figure 6 . In each case, the circles shown represent the failure circle with the minimum factor of safety and they are all equal to or greater than the minimum required by EM 1110-2-1902.

\section{SECTION 7.0 LIOUEFACTION ANALYSIS}

Liquefaction will occur in deposits of sand or silty sands. It does not occur in clays, silty clays or sandy clays. It has occurred in some silts or clayey sands but the occurrence depends on the liquid limits, water content and percent finer than $0.005 \mathrm{~mm}$. Review of the analysis performed by syed Ahmed indicates that these materials do not meet this criteria and therefore are not susceptible to liquefaction. Ahmed's analysis is thorough and complete and this report is in agreement with his findings that liquefaction will not occur.

\section{SECTION 8.0 DISCUSSION OF RESULTS}

8.1 Sections $1-1$ and 2-2: For the two sudden drawdown cases the circles shown on Figures 4 and 5 are not the minimum circles. Circles with factors of safety less that those shown would be more shallow (i.e. the circles would be closer to the face of the slope). However, this is not a concern because any failure that would occur would be superficial and not deep seated and would not affect the overall stability of the structure. For the partial pool and steady state seepage cases, the circles shown are also not the minimum circles. Shallower circles would have lower factors of safety. If failure would occur in shallower circles, however, there would still be a sufficient portion of the dam remaining to prevent loss of the reservoir. The factors of safety for the seismic cases were above 1.0 on the circles shown.

8.2 Section 3-3: For this section, all of the cases resulted in adequate factors of safety. No failure circles should occur that would pose a threat to the safety of the dam.

8.3 Conclusions: Based on the limited information on soil strength and parameters, the stability analyses performed indicated that section 3-3 had adequate factors of safety for the minimum circles found. For sections 1-1 and 2-2, the minimum factors of safety resulted in a marginal threat to the safety of the dam. Should any slope failures occur, they would be shallow and not cause the dam to fail. It can therefore be concluded that the dam is safe and stable for the conditions analyzed. 


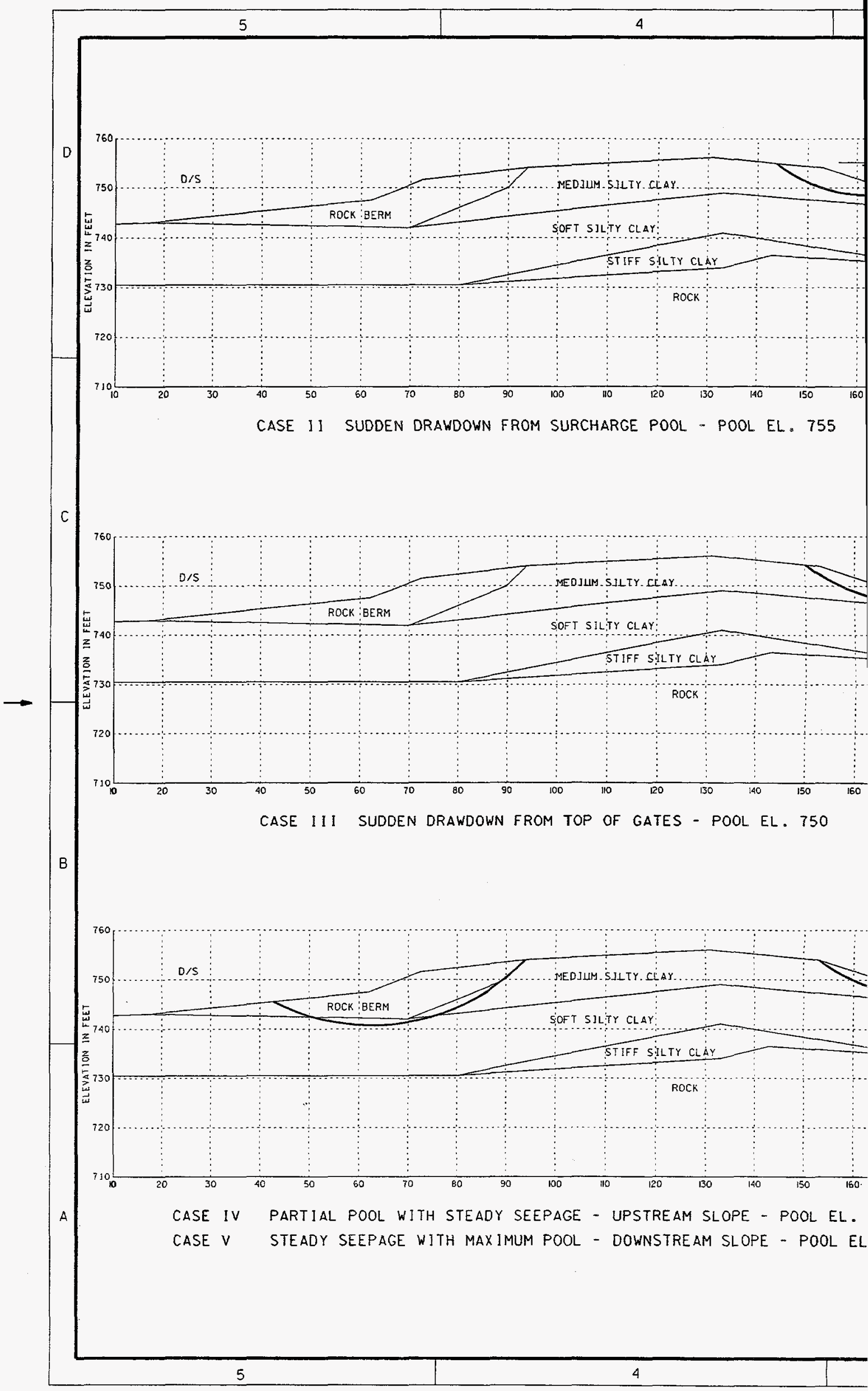



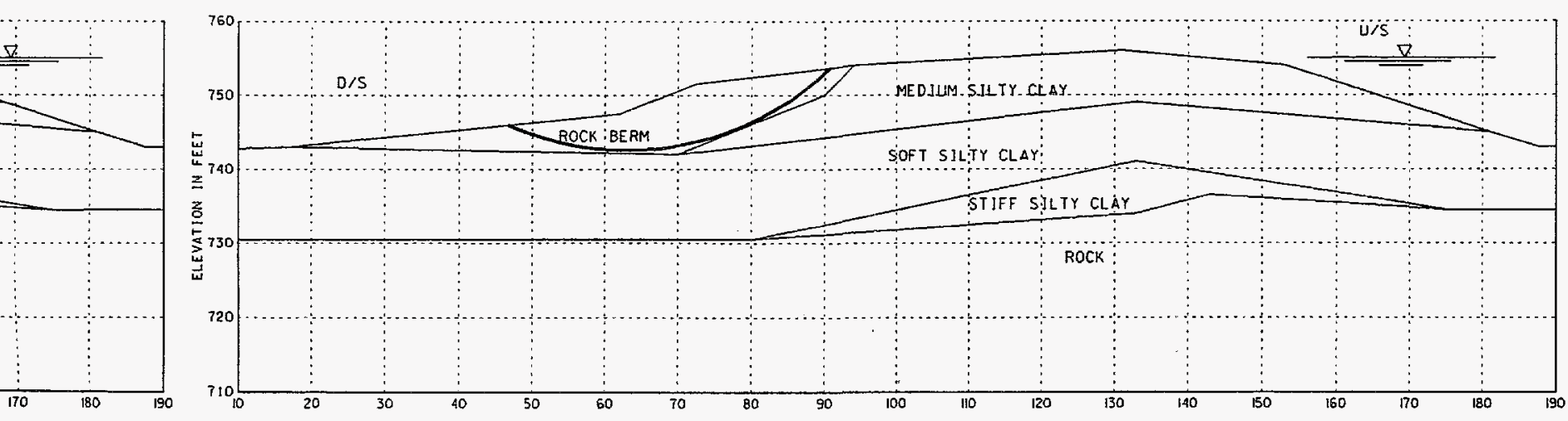

CASE VI STEADY SEEPAGE WITH SURCHARGE POOL - DOWNSTREAM SLOPE - POOL EL. 755
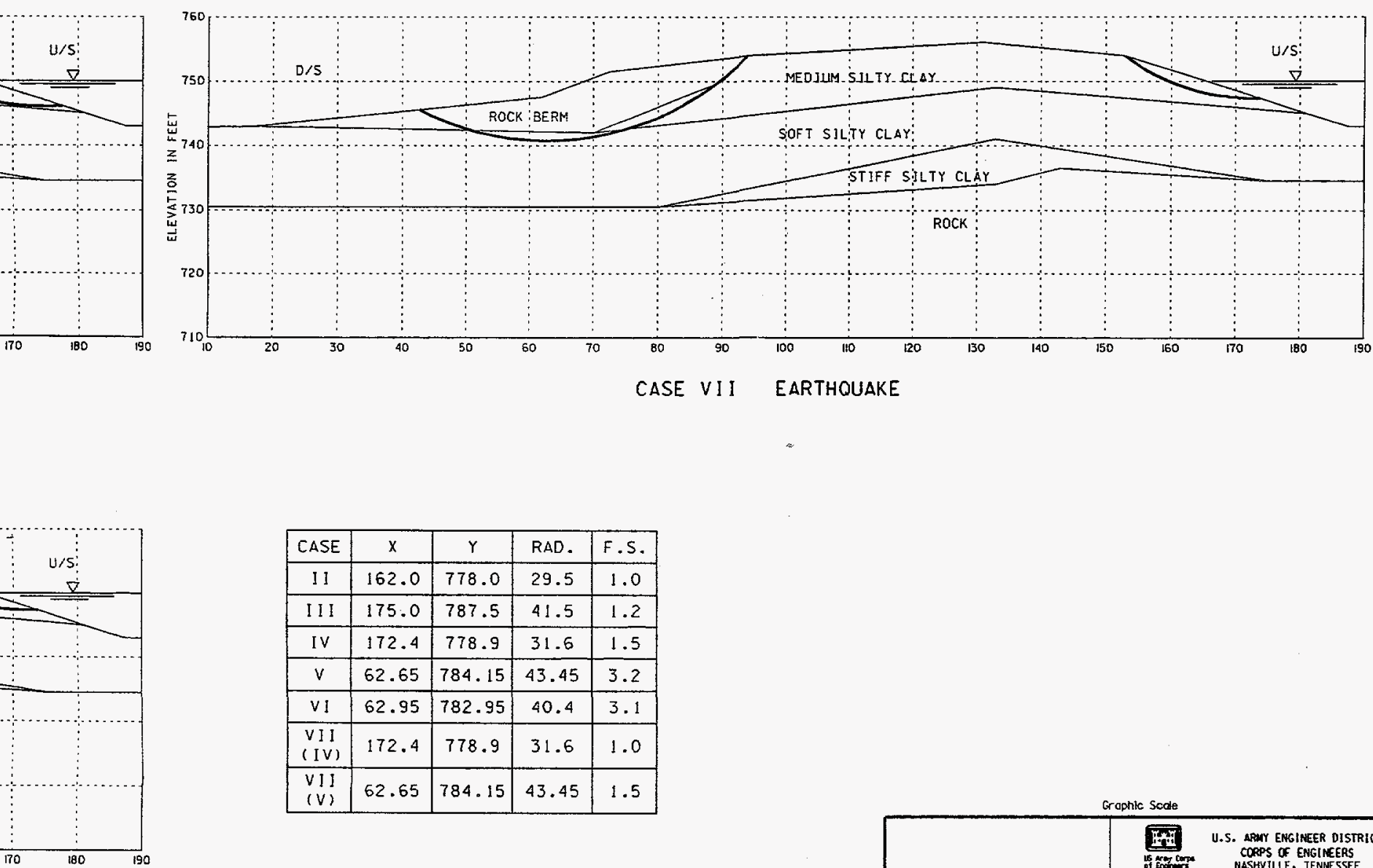

\begin{tabular}{|c|c|c|c|c|}
\hline CASE & $X$ & $Y$ & RAD. & F.S. \\
\hline II & 162.0 & 778.0 & 29.5 & 1.0 \\
\hline III & 175.0 & 787.5 & 41.5 & 1.2 \\
\hline IV & 172.4 & 778.9 & 31.6 & 1.5 \\
\hline V & 62.65 & 784.15 & 43.45 & 3.2 \\
\hline VI & 62.95 & 782.95 & 40.4 & 3.1 \\
\hline $\begin{array}{c}\text { VII } \\
\text { (IV) }\end{array}$ & 172.4 & 778.9 & 31.6 & 1.0 \\
\hline $\begin{array}{c}\text { VII } \\
\text { (V) }\end{array}$ & 62.65 & 784.15 & 43.45 & 1.5 \\
\hline
\end{tabular}

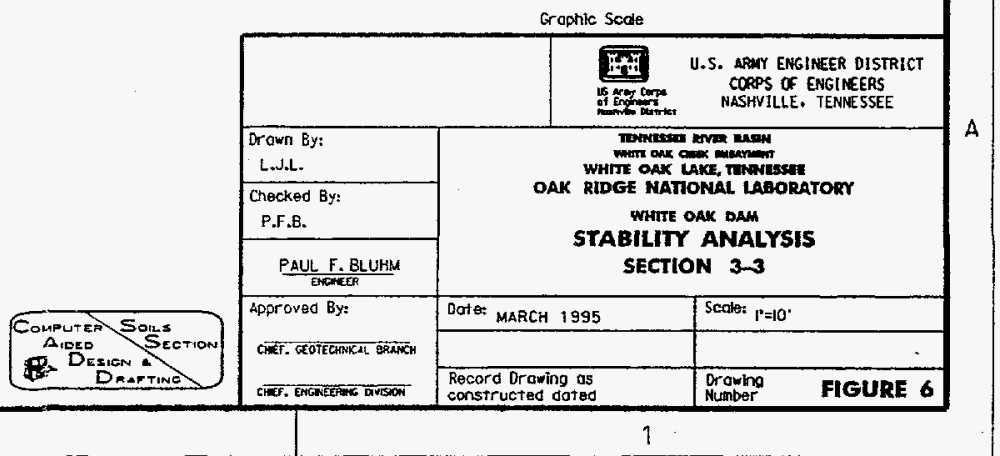




\section{SECTION 9.0 REVIEW AND COMPARISON OF OTHER STUDIES}

9.1 General: The most recent stability analysis on white Oak Dam was that performed by syed B. Ahmed, report X-OE-708, January 1994 . It was based on the same explorations and soil testing as this analysis. The following paragraphs give a comparison of the analysis performed by Ahmed with the analysis in this report.

9.2 Soil profiles: The soil profiles for both analyses were almost identical. Blowcounts were used to determine the boundary lines between the layers, and there seems to be a definite change in blowcounts between the layers.

9.3 Soil Parameters: A comparison between the soil parameters between Ahmed's analysis and this one show that for the most part the soil parameters were about the same. Minor variations can be attributed to interpretation of the test results, however these variations should not affect the outcome of the analysis significantly. The parameters where the two analyses differ are the following:

9.3.1 Unit Weights: For the most part, the unit weights are reasonably close with the exception of the rockfill. Ahmed uses a moist and saturated unit weight of 135 pcf while this analysis uses 120 and 135 pcf, respectively.

9.3.2 Soil strengths: The strengths selected for the rock fill and medium silty clay are about the same. The one triaxial test result for the medium silty clay was essentially interpreted in the same way by both parties. For the stiff silty clay, Ahmed used a cohesion of 200 to 300 psf for the s strength with 27 to 32 degrees phi while this analysis used a cohesion of 275 and a phi of 31 degrees. Thus, at deeper depths the analysis in this report would give higher strengths. The $\mathrm{R}$ strength for the stiff silty clay was about the same for both analyses. For the soft silty clay, Ahmed uses a cohesion of 285 to 425 psf for both the $S$ and $R$ strength whereas this analysis used a cohesion of zero and a phi of 26 degrees for the $S$ strength and a cohesion of 200 psf and 14 degrees phi for the $R$ strength. Again, at deeper depths the analysis in this report gives higher strengths.

It should be noted that cohesion and phi are parameters used to determine the strength of a material for a given condition. Although the parameters selected for the two different analyses are not identical, the magnitudes of the strengths are very close. What is important is how these parameters are applied in the slope stability analysis.

9.4 Slope stability Analysis: There are several differences between the two stability analyses that were performed as noted in the following: 
9.4.1 Cases and Conditions Analyzed: Both Ahmed and this report analyzed the same conditions and cases which are sudden drawdown, steady seepage (downstream slope) and earthquake loading. In this report, one additional case was analyzed which was partial pool (upstream case). It could be argued that the partial pool case represents the normal everyday conditions and since the dam has performed well over the last 50 years this condition need not be analyzed. Although the additional case was analyzed, its result did not have a significant impact on the overall stability of the dam.

9.4.2 Application of Shear strength Parameters: The major difference between the two analyses is how the shear strength parameters were applied. This is discussed below along with how it affected the analyses.

9.4.2.1 Sudden Drawdown: This analysis used the criteria set forth in EM 1110-2-1902 for selection of the shear strength envelope. It uses a combination of the $S$ and $R$ shear strength envelopes, using the envelope that gives the lower strengths depending on what the normal stresses are. This usually means that at low normal stresses (or shallow depths) the $\mathrm{S}$ strength is used. At higher normal stresses (or deeper depths) the $R$ strength is used. Ahmed used the $R$ strength only in his analysis for sudden drawdown.

9.4.2.2 steady seepage: For the steady seepage condition, the strength envelope recommended by EM 1110-2-1902 is to use the $S$ envelope when the $S$ strength is less than the $R$ strength, and a strength envelope midway between the $R$ and $S$ when the $S$ strength is greater than the $\mathrm{R}$ strength. Ahmed used the $\mathrm{S}$ strength only for his analyses. Using the different strength envelopes did not have an effect on the stability analyses for the downstream circles.

9.5 Comments on slope stability Analyses by syed Ahmed: After reviewing the report by Ahmed the following comments are offered.

1. Overall, the analysis is complete and very conservative. The generation of the soil profile and the interpretation of the test results and selection of the soil parameters are well documented and very good justification is provided.

2. Selection of the shear strength envelope to be used in the analysis is, in some respects, a matter of interpretation of the conditions that the soils will be subjected to and the degree of conservatism that the analyst wants to take. The shear strength envelopes that are suggested by the Corps of Engineers EM 1110-21902 are considered to be very conservative. Although the envelopes that Ahmed chose are not as conservative as the Corps', they still represent the lower bound of strengths and he has provided good justification for their selection. 
3. This report is in agreement with the conclusions presented in the Ahmed report which are that the dam is stable during steady seepage, rapid drawdown and seismic events and that the embankment and foundation soils are not susceptible to liquefaction.

\section{Section 10.0 REFERENCES}

1. Ahmed, syed B., "White Oak Dam Stability Analysis", Volumes I and II, Oak Ridge National Laboratory, Martin Marietta Energy System, Inc., Report ORNL/X-OE-708, January 1994.

2. GEOTEK Report, "Evaluation of White Oak Dam" Geotek Project No. 79-687B, dated November 14, 1979 .

3. GEOLOGIC ASSOCIATES, EDGE, Report, "White Oak Dam Investigation" GA File No. 88-X503, dated April 12, 1988.

4. Lovell, C. W. and Johnson, J. M., "Shearing Behavior of Compacted clay after saturation," Laboratory Shear strength of Soil, ASTM STP 740, R. N. Yong and F. C. Townsend, Eds., American Society for Testing and Materials, 1981, pp. 277-293.

5. Bowles, Joseph E., Foundation Analysis and Design, $3 r d$ Edition, New York. McGraw-Hill, Inc.

6. MMES, "Management Plan for White Oak Dam" prepared by Teresa J. Pierce, January 1989.

7. Ogden Environmental and Energy Services, "Formal Inspection Report White Oak Dam", dated January 24, 1994, MMES Contract No. 88B99977V Release C-79.

8. MMES, "Check List for Weekly Inspections of White Oak Dam," January 7, 1991, February 11, 1994, March 28, 1994 and Apri1 5, 11, $15,25,1994$.

9. Edris, Jr., Eael V., and Wright, Stephen G., 1987, "User's Guide: UTEXAS2 slope stability Package, Volume I," Department of the Army, Waterways Experiment station, Corps of Engineers.

10. Department of the Army, Corps of Engineers, "Engineering and Design Stability of Earth And Rock-Fill Dams," April 1970 Engineering Manual 1110-2-1902. 